\title{
Developing and Using Multimedia Effectively for Cirebonese Language Learning
}

\author{
Ahmad Ripai ${ }^{1}$, Basuki Wibawa ${ }^{2}$, and Asmaniar Z. Idris ${ }^{2}$ \\ ${ }^{1}$ Jakarta State of University \\ ${ }^{2}$ Faculty of Engineering, Jakarta State University
}

\section{Abstract}

This study employs the research and development model of Borg \& Gall and Dick \& Carey involving students of SMPN 4 Kota Cirebon. This study aims to develop and using effectively multimedia Cirebonese language learning for the junior high school of the eleventh-grade students. To find out the results of the content of multimedia, instructional design and instructional media experts validation were conducted. In addition, individual, group, and field try-out were conducted. The try-out process involved the experts of Cirebonese language media and instructional design. It also involved 6 students for an individual (one to one) try-out, 15 students for group, and

Corresponding Author:

Ahmad Ripai

email: ahmadri-

pai_tp10s3@mahasiswa.unj.ac.id

Received: 11 January 2019

Accepted: 14 February 2019

Published: 25 March 2019

Publishing services provided by Knowledge E

(c) Ahmad Ripai et al. This article is distributed under the terms of the Creative Commons

Attribution License, which

permits unrestricted use and redistribution provided that the original author and source are credited.

Selection and Peer-review unde the responsibility of the $3 \mathrm{rd}$ ICTVET 2018 Conference Committee.

\section{G OPEN ACCESS}

34 students for the field try-out. The results showed, first, because $t, 3,0569 \mathrm{E}-18$ or $=$ $3.0569 \times 10-18$ smaller than $t$-table at a significance level $(\alpha)$ amounted to 2.034515 0.05 , it rejects $\mathrm{Ho}$ and accepts $\mathrm{Ha}$. It can be concluded that the Cirebonese language learning using developed instructional multimedia is effective in improving students' learning outcomes.

\section{Keywords: development, multimedia, Cirebonese language learning}

\section{Introduction}

Information technology in recent years have grown very rapidly, thus changing the paradigm of the community in seeking and obtaining the information is no longer limited to information newspapers, audio-visual and electronic, but also sources of other information on them through the Internet. The influence of the development of information and communication technologies in the learning process is marked by the emergence of a variety of educational media from simple educational media, development of instructional media to internet-based learning. The development of instructional technology in education promises great potential for changing the way a person to learn, to obtain information, to customize information and others. 
Learning media also provides an opportunity for educators to develop learning techniques so as to get maximum results. For instance, for students, the use of learning media is expected to make them easier to get the information because they do not reach from merely the textbook. The ability of instructional media technology has developed rapidly and will further add to the ease in getting information for the sake of learning. In learning activities, teachers are often encountered with abstract material and beyond the everyday experience of students. As a consequence, teachers get some difficulties to provide some teaching material and students get some problems to understand. Visualization is one way that can be done to make something abstract to be real. Images the two-dimensional or three-dimensional model is a visualization that is often used in the learning process. Visualization in the learning process develops in the form of moving images (animation) that can be added to the sound (audio). Serving audiovisual or better known as the learning media is expected to make the visualization more attractive.

Edgar Dale in Heinrich Robert et al. described the importance of visualization and verbalist learning experience called "Edgar Dale Cone experience". According to Edgar Dale in (Heinich, Molenda, Russell \& Smaldino, 1996: 16) that there is a continuum from the concrete to the abstract between direct experience, visual and verbal in instilling a concept or understanding. The more concrete experiences will be better to ensure the learning process. Thus, that visualization is easier for people to grasp the understanding.

Cirebon language lesson, which is the local content subjects in the learning process still face many obstacles. For instances, teachers have not met in accordance with the required qualifications and competencies, lack of learning tools that support unavailability of teaching media. Other factors are the lack of interest of students in learning Cirebonese language and inadequate allocation of instructional time also hindered the learning process a Cirebonese language lesson. These obstacles are very influential in the language learning process and results of Cirebon. The effort to facilitate the Cirebonese language learning process using media has prompted researchers to develop instructional media for this subject. Research question 1) how to develop interactive multimedia in Cirebon language learning?, and2) how to effectiveness of interactive in the language Cirebon learning?

\subsection{Multimedia}

meaning a lot or mixed. The word media comes from the Latin media, the medium which means the intermediary or something that is used to deliver, convey or carry something, 
(Munir, 2012: 8). Multimedia is a tool that can create a dynamic and interactive presentations, that the combine text, graphics, animation, audio and video and image video (Robin and Linda, in Famukhit, et al. (2013). Tay Vaughan (2008: 1), defines the multimedia is a combination of various media texts, images, video, music or handwritten. For the computer, the information for, all prepared from digital data. Oblinger in Munir (2012: 2), defines the multimedia represents the union of two or more communication media such as text, graphics, animation, audio and video with the characteristics of computer interactivity to generate the attractive presentation. Meanwhile, Mayer believes that using a multimedia presentation of material can directly use both of the words and pictures at the same time. The definition of 'words' here is the material presented in the form of verbal or verbal form, for example using text words printed or uttered. What is meant by 'image' is the material presented in pictorial form or shape of the image, can be in the form of static graphics (illustrations, graphs, photos and maps), or use dynamic charts (animation and video (Richard E. Mayer, 2009: 2-3 ).

Plomp \& Ely multimedia is described as a dynamic process of transformation of technologies to develop and to progress in making the understanding, and its name changes from years to years such as interactive video, interactive media, the combination of media, hypermedia and multimedia. Multimedia packaged as a product uses more than one medium as a communications tool, for example, text, images, movies, sound, graphics and animation in various combinations. They are integrated for use with computers that make it easier to interact (Tjeerd Plomp \& Donald P.Ely, 1996: 221).

\section{Methods and Step-step of Research}

\subsection{Methods}

This research adopts the development of research known Research and Development (R \& D). Research and development in education is a process to develop and validate a product of education including material objects and procedures such as media, methods and learning

models. In accordance with this definition, this research seeks to produce effective and interactive learning media. This research and development are carried out with reference to the model of research and development formulated by, Borg \& Gall which has been adapted from the steps of instructional design Dick and Carey. These steps are called by Borg \& Gall as The Step of the System Approach Model of Educational Research and Development (R \& D) (1983: 569-571) which includes the steps as follows: 
1) identify instructional goal(s), 2) conduct instructional analysis, 3) analyze learners and context, 4) write performance objective, 5) develop assessment instrument, 6) develop instructional strategies, 7) develop and select materials /instructional media, 8) Design and implement formative evaluation of instruction, 9) revise instructional activities, 10) design and implement summative evaluation. These steps are illustrated in the figure below:

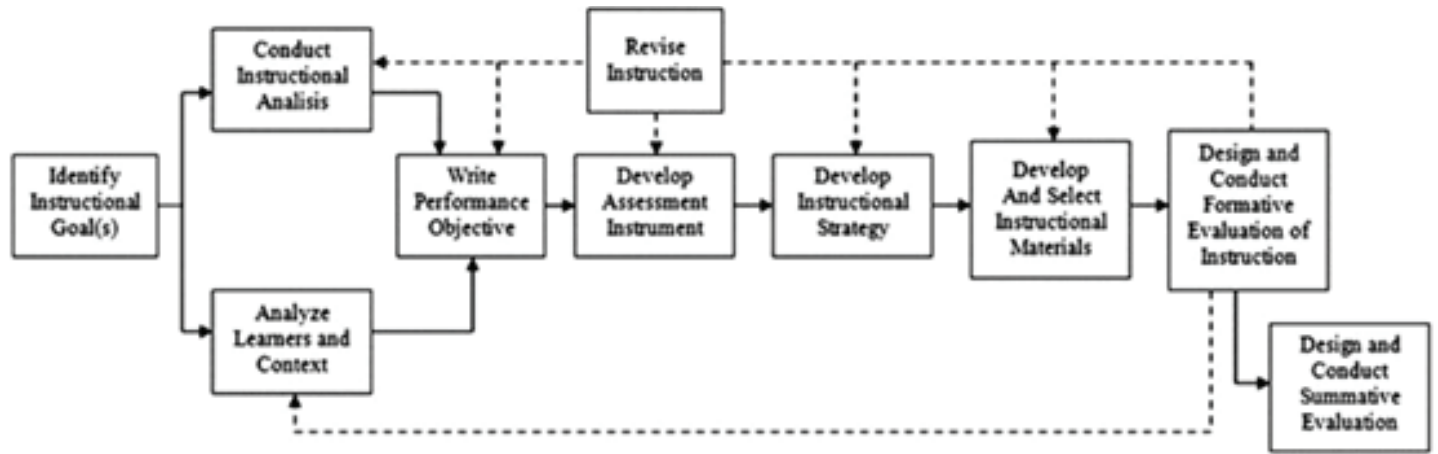

Figure 1: The Step of the System Approach Model of Educational Research and Development.

\subsection{Step-step of research}

\subsubsection{Development planning}

In designing and developing learning multimedia of Cirebonese language, it consists of a conceptual model design, procedural models and physical models. In the conceptual model in this research is based on the design of learning multimedia. The design of this learning multimedia is produced based on the principles of development models which refer to theoretical studies, and analytical results and needs.

Procedural model employed Dick \& Carey's development design which consists of three main stages of the systems approach a) identifying the stages; b) developing stage, c) the stage of evaluating and revising (Supaman, 2004: 13)

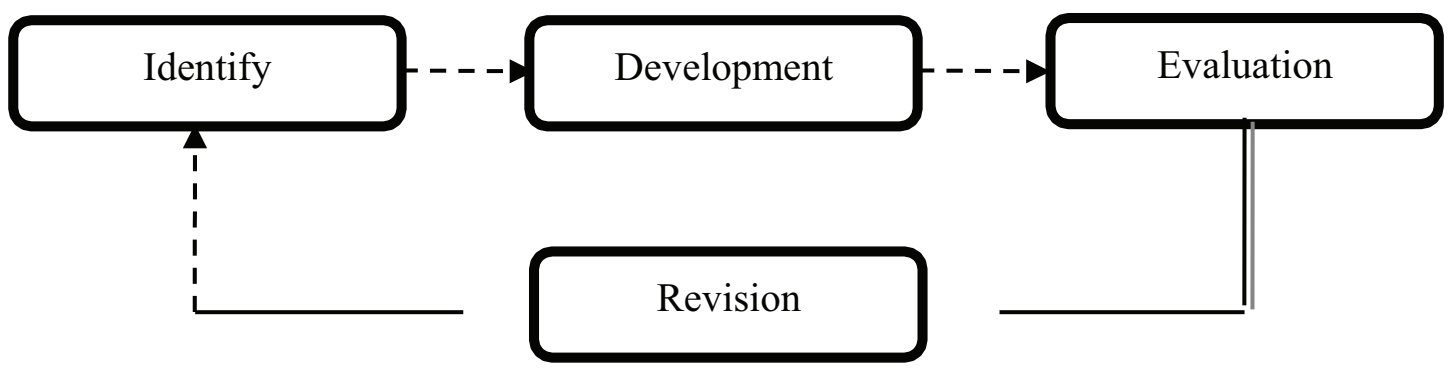

Figure 2: Chart Systems Approach. 


\subsubsection{Validation, evaluation multimedia specialist/expert validation}

Experts validation is conducted to obtain information about the suitability of the material with the learning objective, the concept of truth, the latest material, as well as

the scope and depth of the material. In this research, expert validation is conducted by a Cirebonese language expert, media specialists, and instructional design experts.

\section{Evaluation one (One to one)}

Evaluation of one to one (1-1) is committed to measuring six students who have the capability of high, medium and low. At this stage, the evaluation is done to get information about the readability of the material, the focus of the material and attractiveness of the product.

\section{Trial for small group (Small group try-out)}

Evaluation is conducted on small groups involving eight to twelve students. Learning is done like a real situation, but with a fewer number of students. At this stage, the evaluation was the same as the evaluation of one to one in order to get information on student feedback about the legibility of the material, the material focus and attractiveness of the product. The difference from the previous one is on the instrument used in the form of questionnaires, whereas in this stage the evaluation instrument used is one to one interviews.

\section{Field trial (Field try-out)}

Field trials involve large groups which are equivalent to the real target. In this final phase, the evaluation is conducted to obtain comprehensive information about the quality and effectiveness of interactive media for Cirebonese language learning products. Field trials were conducted in class IX students of SMPN 4 cities Cirebon.

\section{Result}


3.1. Product interactive multimedia of Cirebon language learning

Finally, Cirebonese language learning media can be final product (final draft) after being revised which is feasible theoretically and empirically.

Display learning multimedia of Cirebonese language:
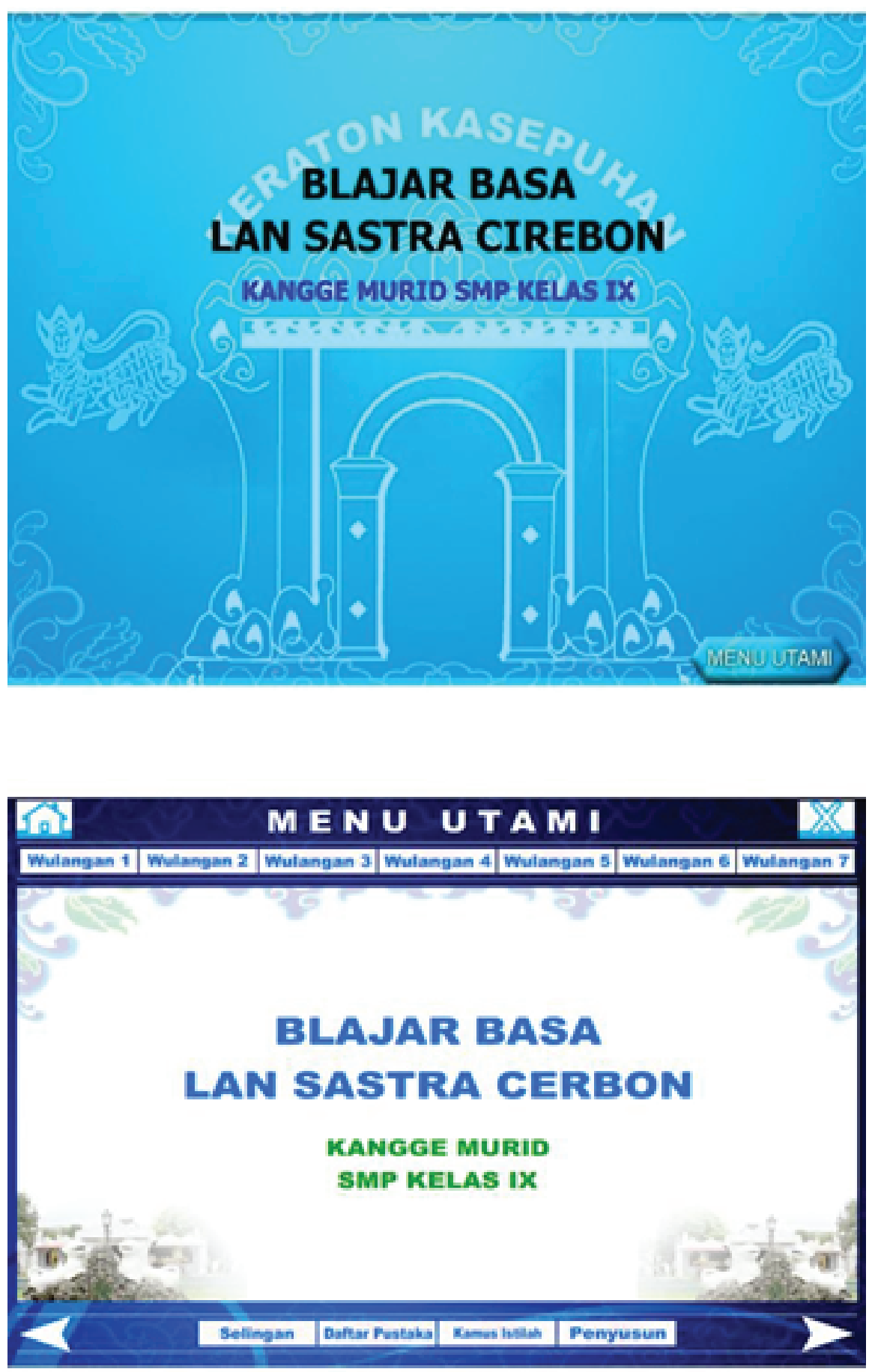


\subsection{Using effectiveness multimedia}

To measure the effectiveness of Cirebonese language learning multimedia program which has been developed, the authors perform the following steps:

\subsubsection{Conducting pre- and post-test}

To determine the effectiveness of the program, pretests and final tests are conducted to see the extent to which the developed product can improve learning outcomes or achievement of learning objectives. The final test given to students after participating in learning activities is in the form of formative test. Its function is expected to obtain the data regarding developed language learning media program for Cirebonese subject.

\subsubsection{T-test}

Initial test scores and final tests of learning analyzed by paired $T$-test, refer to a design of experiments (one-group pretest-posttest design O X O). (David R Krathwohl, 1998: .509-Because the $T$-test is one test of basic statistical inference in statistical analysis $t$-test assumptions include properties "robust" then, the assumptions of normality and homogeneity of variance might not be a serious problem (if neglected). Thus, it is assumed normal and homogenous population. (Nancy L Leech, Karent C. Barrett and George A. Morgan, 2005: 27-28).

$$
t=\frac{\overline{X_{1}}-\overline{X_{2}}}{\sqrt{\left(\frac{\sum x_{1}^{2}+\sum x_{2}^{2}}{n_{1}+n_{2}-2}\right)\left(\frac{1}{n_{1}}+\frac{1}{n_{2}}\right)}}
$$

\subsubsection{Effectiveness test of multimedia}

To determine the usefulness of the multimedia program, the effectiveness test conducted. This test is in the form of the pretest and posttest which aims to determine the extent to which developed products can improve learning outcomes expected. The results of pre-tests and post-tests are described as follows: The data above is analyzed using $t$-test with the Microsoft Excel program and it shows in the following table:

Based on the Table 4.10, it can be concluded that: First, Because $t, 3,0569 \mathrm{E}-18$ or $=$ $3.0569 \times 10-18$ is smaller than $t$-table at a significance level $(\alpha)$ amounted to 2.034515 0.05 , then it rejects $\mathrm{HO}$ and accepts $\mathrm{Ha}$. It concluded that the Cirebonese language learning process using developed instructional media program is effective in improving 
TABLE 1: $t$-Test: Paired Two Sample for Means.

\begin{tabular}{l|c|c|} 
& Post-Test & Pre-Test \\
\hline Mean & 65,88235294 & 50,44117647 \\
\hline Variance & 53,74331551 & 50,557041 \\
\hline Observations & 34 & \\
\hline Pearson Correlation & 0,733519027 & \\
\hline Hypothesized Mean Difference & 0 & \\
Df & 33 & \\
$t$-Stat & 17,06730894 \\
\hline P(T <= t) one-tail & $3,0569 \mathrm{E}-18$ & \\
$t$ Critical one-tail & 1,692360258 & \\
\hline P(T <= t) two-tail & $6,1138 \mathrm{E}-18$ & \\
$t$ Critical two-tail & 2,034515287 & \\
$t$-table: 2.034515 & & \\
\hline interpretation: & &
\end{tabular}

students' learning outcomes. Second, mean scores after using Cirebonese language learning media is higher (better) than before using it. It is shown in the table Paired Sample Statistics, where the mean score before using amounted 50.44117647. While the mean score after using media language learning Cirebon amounted 65.88235294. This means that Cirebonese language learning media has a positive effect. Thirdly, Cirebonese language learning media program had a positive influence. Hence the decision to develop a media program on Cirebonese language subject has practical significance.

\section{Conclusion}

Therefore, the use of Cirebonese language learning multimedia had a positive influence, then the decision to develop a multimedia program for Cirebonese language learning media has practical significance.

\section{References}

[1] Borg, W. R. \& Gall, M. D. Educational research: an introduction (7th ed.). New York: Longman, Inc, 2003.

[2] Carey, Dick, W, L. \& Carey, J. O. The systematic design of instruction. Boston: Harper Collin College Publisher, 2005. 
[3] Famukhit, Muga Linggar, Maryono, Bambang Eka Purnama and Lies Yulianta (2013), Interactive Application Development Policy Object 3D Virtual Tour History Pacitan District Based Multimedia, International Journal Of Advanced Computer Science And Application (IJACSA, Vol.4 No.3

[4] Heinrich, Robert, Michael Molenda, James Russel \& Sharone E. Smaldino. Instructional Media And Technologies For Learning. New York: Macmillan Publishing Company, 1996.

[5] Krathwohl, David R. Methods of Educational and Social Science Research: An Integrated Approach. Second Edition, New York: Longman, 1998.

[6] Leech, Nancy L, Karen C. Barrett and George A. Morgan. SPS for Intermediate Statistics: Use and Interpretation. Second Edition London: Lawrence Erlbaum Associates Publishers, 2005.

[7] Mayer, Richard E. Multimedia Learning: Prinsip-Prinsip dan Aplikasi. terj. Teguh Wahyu Utomo, Yogyakarta: Pustaka Pelajar, 2009.

[8] Munir. Multimedia: Konsep dan Aplikasinya Dalam Pendidikan. Bandung: Alfabeta, 2012.

[9] Plomp, Tjeerd \& Donald P.Ely (ed.), International Encyclopedia of Educational Technology-Second Edition. Cambridge: University Press, 1996.

[10] Sadiman, Arif S. dkk. Media Pendidikan; Pengertian, Pengembangan dan Pemanfanfaatanya. Jakarta: CV. Rajawali, Pustekom Diknas, 1990.

[11] Suparman, Atwi, Desain Instruksional. Jakarta: Pusat Penerbitan Universitas Terbuka, 2004.

[12] Vaughan, Tay. (2008). Multimedia: Making It Work, Seven Edition, New York: McGraw Hill. 